\title{
ANTIOXIDANT AND ANTIULCER ACTIVITY OF ABRUS PRECATORIUS LEAF EXTRACT AGAINST ACETIC ACID-INDUCED GASTRIC ULCER IN RATS
}

\section{LALITA NAGDA*, CHANDRA PRAKASH JOSHI, JYOTI MENARIA}

\author{
Department of Pharmacology, Geetanjali Institute of Pharmacy, Udaipur, Rajasthan, India. Email: lalitanagda22@gmail.com
}

Received: 06 March 2019, Revised and Accepted: 28 May 2019

\begin{abstract}
Objective: The present study deals with the study of antiulcer activity of Abrus precatorius leaf extract in acetic acid-induced gastric ulcers was studied in rats.

Methods: In the present study, A. precatorius leaf extract was carried out in antiulcer activity against acetic acid-induced gastric ulcer in rats. A. precatorius at doses of $150 \mathrm{mg} / \mathrm{kg}$ and $300 \mathrm{mg} / \mathrm{kg}$ were administered orally once daily for 10 days.

Results: It was found that extract significantly reduced ulcer index. The plant leaves made gastric anti-secretory effect by decreasing gastric volume and acidity. Then, gastric mucin was increased, which showed gastric cytoprotective effect. The plant showed the prevention effect of increased lipid peroxidation during ulceration by acetic acid. Activities of the antioxidant enzymes were enhanced during ulceration by this plant leaves.
\end{abstract}

Conclusion: Leaves of $A$. precatorius Linn. could decrease acetic acid-induced gastric ulcers in rats and this antiulcerogenic activity was mediated through antioxidant defense mechanism.

Keywords: Alcoholic extract, Acetic acid, Omeprazole, Gastric ulcer.

(C) 2019 The Authors. Published by Innovare Academic Sciences Pvt Ltd. This is an open access article under the CC BY license (http://creativecommons. org/licenses/by/4. 0/) DOI: http://dx.doi.org/10.22159/ajpcr.2019.v12i7.32909

\section{INTRODUCTION}

A. precatorius Linn. has been used in Hindu medicines from very early times, as well as in China and other ancient cultures [1]. The plant was considered beneficial for the hair and the seeds extract is used in the treatment of ulcer and skin infection [2]. Seeds of the plant are very much attractive, used in ornaments, but are highly poisonous. Seeds are used as antidiabetic activity, antioxidative activity, antibacterial, and anti-inflammatory analgesic activity [3-6]. Other uses of the plant are observed in cancer and in malaria [7,8]. Phytochemical constituents of the plant are abricin, abrin, abrisin, abrine, abraline, abrasine, abrusgenic acid methyl ester, abruslectone, abrussic acid, anthocyanins, etc. [9]. Anti-peptic ulcer activity of the leaves of A. precatorius Linn. in albino rats was also observed [10]. In the present study, the effect of A. precatorius Linn. leaves on acetic acid-induced gastric ulcer in albino rats and the possible mechanism involved therein are being reported.

\section{MATERIALS AND METHODS}

\section{Plant material and authentication of plant}

A. precatorius Linn. leaves were collected in the month of July 2017 from herbal garden of College of Pharmacy, Geetanjali University, Udaipur, and identified by Dr. Smriti Foujdar, Associated Professor, Banasthali Vidyapith, Jaipur. The collected leaves were shade dried and then crushed to coarse powder with mechanical grinder. The powder was stored in air-tight container which was used for extraction.

\section{Preparation of extract}

The collected leaves were treated 2-3 times with tap water to remove adhering dust and allowed to dry in shade. The dried material was crushed to coarse powder with mechanical grinder. It was then passed through sieve number of 40 . A weighed quantity ( $150 \mathrm{~g}$ ) of the powder was subjected to continuous hot extraction in Soxhlet apparatus with ethanol as a solvent and extracted until the solvent became colorless. Extract was then evaporated by vacuum evaporator.

\section{Chemicals}

All chemicals (Laboratory reagent) were purchased from (Central Drug House) R. S. Enterprises, Jaipur.

\section{Experimental animals}

Albino rats (150-200 g) of either sex were used for the study. Rats were kept for at least a week in the experimental wing of the animal house at $25^{\circ} \mathrm{C}-28^{\circ} \mathrm{C}$ and humidity $60 \%-65 \%$ with $12 \mathrm{~h}$ light and dark cycle. Animals were fed on laboratory diet with water ad libitum. Six rats were used for each set of experiment. The animal experiment was approved by the Ethics Committee of Geetanjali University.

\section{Acute toxicity study}

Albino rats of either sex weighing 150-200 g were used in the study. Acute oral toxicity study was performed as per OECD-423 guideline. The animals were divided into three groups $(n=3)$ and were fasted overnight before drug administration.

\section{Experimental procedure}

\section{Induction of gastric ulcer}

Albino rats of either sex weighing between 150 and $200 \mathrm{~g}$ were selected and divided into five groups $(\mathrm{n}=6)$ animals. Overnight fasted rats treated with ether anesthesia, anterior and posterior walls of stomach clamped with forceps. About $0.2 \mathrm{ml}$ of $40 \%$ acetic acid solution was injected into clamped portion. After $45 \mathrm{~s}$, acid removed, deep round ulcers developed on anterior and posterior walls. Respective treatments (control, standard, and test) were started on the $3^{\text {rd }}-10^{\text {th }}$ days. Rat sacrificed on the $10^{\text {th }}$ day. The stomach was removed and the gastric lesions were evaluated by examining the inner gastric surface.

- Group I: Normal control

- Group II: Acetic acid induced (40\% acetic acid $0.2 \mathrm{ml}$ in subserosal membrane)

- Group III: $20 \mathrm{mg} / \mathrm{kg}$ omeprazole + Acetic acid

- Group IV: Ethanolic extract of A. precatorius at a dose of $150 \mathrm{mg} / \mathrm{kg}$ + Acetic acid 
- Group V: Ethanolic extract of A. precatorius at a dose of $300 \mathrm{mg} / \mathrm{kg}$ + Acetic acid.

\section{Ulcer index}

After the incision of the stomach at the greater curvature, the ulcers were observed. Moreover, the number of ulcers was counted using a magnifying glass and the diameter of the ulcers was measured using Vernier calipers. The following arbitrary scoring system was used to grade the incidence and severity of lesions [11].

- The ulcer index was determined using the formula Ulcer index $=10 / \mathrm{X}$

Where, $\mathrm{X}=$ Total mucosal area/Total ulcerated area

- Based on their intensity, the ulcers were given scores as follows: $0=$ no ulcer, 1 = superficial mucosal erosion, 2 = deep ulcer or transmural necrosis, and 3 = perforated or penetrated ulcer

- Percentage protection was calculated using the formula

Percentage protection $=100-\mathrm{U}_{t} / \mathrm{U}_{c} \times 100$

Where, $U_{t}=$ Ulcer index of treated group

$\mathrm{U}_{c}=$ Ulcer index of control group.

\section{Biochemical estimations}

Collected gastricjuice from the rat's stomach was centrifuged and its volume and $\mathrm{pH}$ were measured. Gastric juice was further used for the estimation of free and total acidity as described by Solanki et al. [12], pepsin content by the method of Satyavati et al. [13], mucin by our methods, and total protein by the method of Molgaard et al. and Rashmi et al. [14,15]

\section{Statistical analysis}

The values were expressed as mean \pm standard error of mean and were analyzed using one-way analysis of variance using the Statistical Package for the Social Sciences (SPSS) $20^{\text {th }}$ version. Differences between means were tested employing Duncan's multiple comparison test and statistical significance was set at $\mathrm{p}<0.05$.

\section{RESULTS AND DISCUSSION}

\section{Acute toxicity study}

Result of acute oral administration of powdered leaves of $A$. precatorius Linn. in various doses of $0.1,0.6,1,4$, and $5 \mathrm{~g} / \mathrm{kg}$ indicated no mortality up to $72 \mathrm{~h}$ after treatment. All rats were healthy and active during the experimental period.

\section{Antigastric ulcer activity of $A$. precatorius Linn.}

Results relating to the effects of $A$. precatorius Linn. and omeprazole against acetic acid-induced gastric ulcer in rats are shown in Table 1.

Acetic acid produced massive ulcers in glandular part of rat's stomach. Incidence of ulceration was $100 \%$. Acute dilatation and hemorrhage were seen in stomach. In one rat, perforation of the stomach was noted. Ulcer index came $72.04 \pm 1.54$. Pre-treatment of rats with $A$. precatorius

Table 1: Effect of Abrus precatorius Linn. leaves extract acetic acid-induced gastric ulcer in albino rats

\begin{tabular}{lll}
\hline Group & Ulcer index & $\begin{array}{l}\text { Percentage } \\
\text { ulcer protection }\end{array}$ \\
\hline $\begin{array}{l}\text { Group I - control } \\
\text { (normal) }\end{array}$ & $1.24 \pm 2.22$ & 92 \\
$\begin{array}{l}\text { Group II - acetic } \\
\text { acid (disease control) }\end{array}$ & $72.04 \pm 1.54$ & - \\
$\begin{array}{l}\text { Group III - acetic } \\
\text { acid+omeprazole } \\
(20 \mathrm{mg} / \mathrm{kg} \text { ) }\end{array}$ & $9.32 \pm 2.10^{* *}$ & 87.62 \\
$\begin{array}{l}\text { Group IV - acetic } \\
\text { acid+APE (150 mg/kg) }\end{array}$ & $45.82 \pm 2.00^{*}$ & 28.76 \\
$\begin{array}{l}\text { Group V - acetic } \\
\text { acid+APE }(300 \mathrm{mg} / \mathrm{kg})\end{array}$ & $35.91 \pm 1.54^{* *}$ & 54.89 \\
\hline
\end{tabular}

Results were in mean \pm SEM, each group had six rats, ${ }^{*} \mathrm{p}<0.05,{ }^{* *} \mathrm{p}<0.001$.

SEM: Standard error of mean, APE: Abrus precatorius extracts
Linn. leaves gave significant protection $(28.76 \%$, and $54.89 \%$ by the doses of $150 \mathrm{mg} / \mathrm{kg}$ and $300 \mathrm{mg} / \mathrm{kg}$, respectively) to the animals from forming ulcers by acetic acid. Omeprazole (20 mg/kg), however, gave $87.62 \%$ protection.

\section{Anti-secretory effect}

Results are shown in Table 2.

In control rats, volume and $\mathrm{pH}$ of gastric juice were $1.36 \pm 0.05$ and $1.92 \pm 0.09$, respectively. Acetic acid increased volume of gastric juice $(3.68 \pm 0.06)$ and decreased its $\mathrm{pH}(1.63 \pm 0.07)$ in rats. Changes were statistically significant $(\mathrm{p}<0.001)$. Pre-treatment of rats with A. precatorius Linn. leaves, however, could decrease volume of gastric juice $(1.868 \pm 0.08)$ and increase its $\mathrm{pH}(2.8 \pm 0.06)$. Effects were comparable to that of omeprazole as in this group gastric juice; volume and $\mathrm{pH}$ were $1.35 \pm 0.05$ and $4.14 \pm 0.12$, respectively.

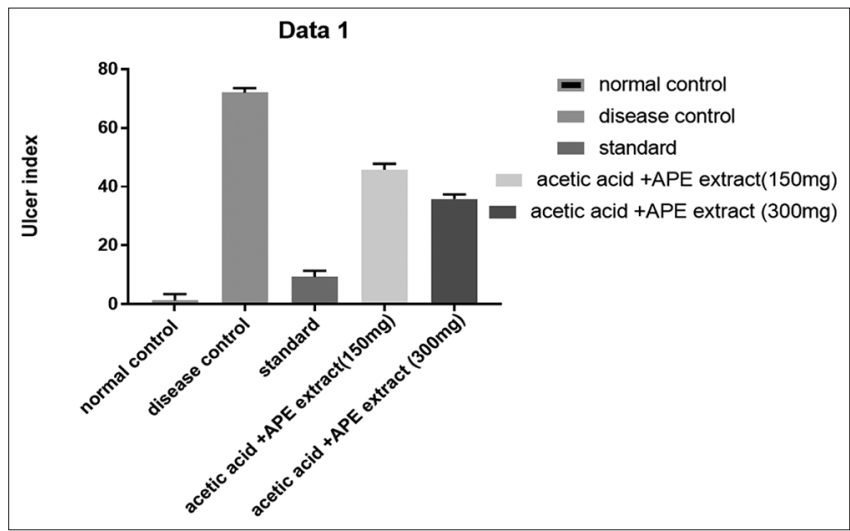

Fig. 1: Graphical representative of ulcer index (\%)

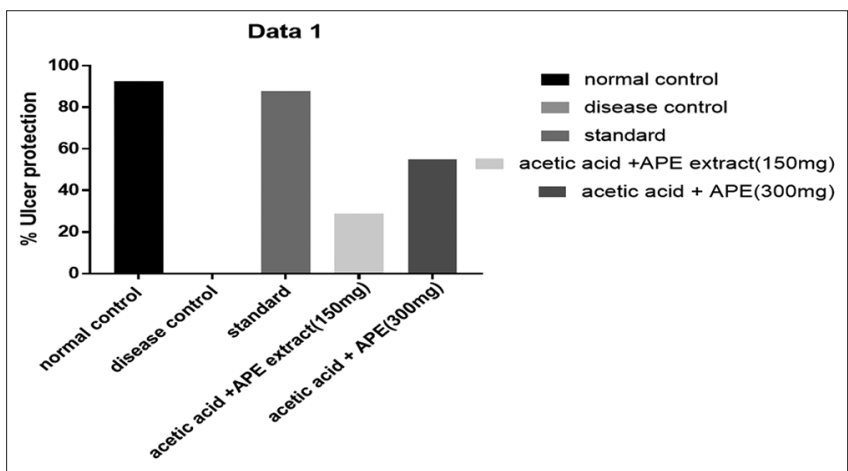

Fig. 2: Graphical representative of percentage ulcer protection

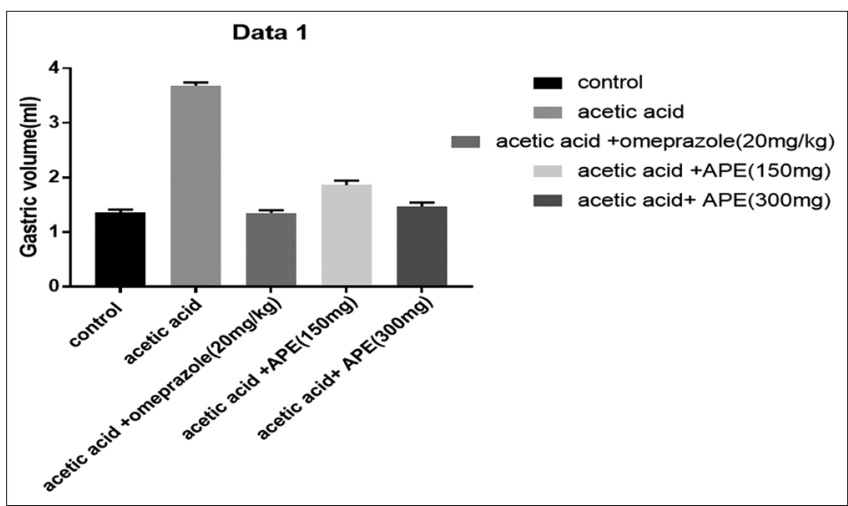

Fig. 3: Graphical representative of gastric volume $(\mathrm{ml})$ 


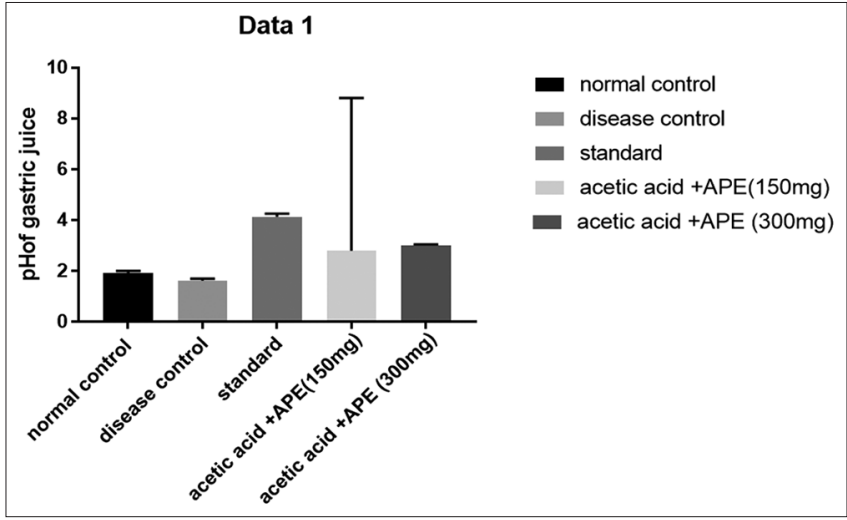

Fig. 4: Graphical representative of $\mathrm{pH}$ of gastric juice

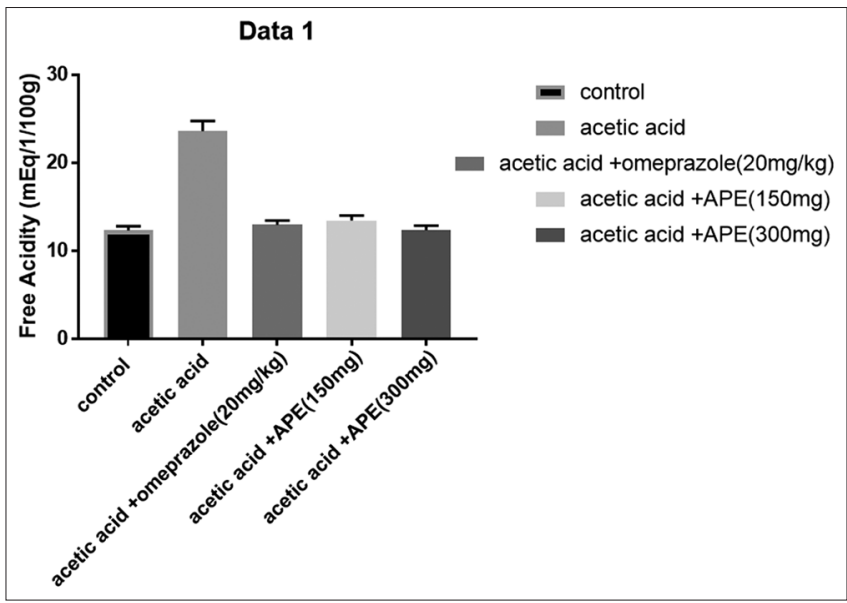

Fig. 5: Graphical representative of free acidity

Effect of $A$. precatorius Linn. leaves on gastric acidity

Table 3 showed effects of $A$. precatorius Linn. leaves and omeprazole on free and total acidity of gastric juice during acetic acid-induced gastric ulcer in rats.

Omeprazole significantly increased both free and total gastric acidity. Free and total gastric acidity of control rats were $12.31 \pm 0.48$ and $32.29 \pm 0.54$, respectively. For acetic acid group values came $23.60 \pm$ 1.16 (free acidity) and $74.24 \pm 2.93$ (total acidity). A. precatorius Linn. leaves could decrease free and total gastric acidity (13.45 \pm 0.57 and $43.76 \pm 0.95$, respectively). Omeprazole also decreased raised free and total gastric acidity during acetic acid-induced gastric ulcers.

\section{CONCLUSION}

Leaves of A. precatorius Linn. could decrease acetic acid-induced gastric ulcers in rats and this antiulcerogenic activity was mediated through antioxidant defense mechanism.

This antiulcer activity is helpful in further experimental analysis in future.

\section{REFERENCES}

1. Bejoy G. The Medicinal Plants of Sikkim Himalaya. Gangtok, Sikkim: Jasmin Bijoy Gurung; 2002. p. 4.

2. Chopra RN, Chopra IC. Indigenous Drops of India. Kolkata: U. N Dhar and Sons Private Limited; 1958. p. 361.

3. Monago CC. Alumanah EO. Antidiabetic effect of chloroform-methanol extract of Abrus precatorium Linn. seed in alloxan diabetic rabbits.
Table 2: Effect of Abrus precatorius Linn. leaves on volume and $\mathrm{pH}$ of gastric juice during acetic acid-induced gastric ulcer in albino rats

\begin{tabular}{lll}
\hline Group & $\begin{array}{l}\text { Gastric } \\
\text { volume }(\mathrm{ml})\end{array}$ & $\begin{array}{l}\text { pH of } \\
\text { gastric juice }\end{array}$ \\
\hline Control (normal) & $1.36 \pm 0.05$ & $1.92 \pm 0.09^{* *}$ \\
Acetic acid (disease control) & $3.68 \pm 0.06^{* *}$ & $1.63 \pm 0.07^{* *}$ \\
Acetic acid+omeprazole & $1.35 \pm 0.05^{* *}$ & $4.14 \pm 0.12^{* *}$ \\
$(20 \mathrm{mg} / \mathrm{kg})$ & & \\
Acetic acid+APE $(150 \mathrm{mg})$ & $1.868 \pm 0.08^{* *}$ & $2.8 \pm 0.06^{* *}$ \\
Acetic acid+APE $(300 \mathrm{mg})$ & $1.478 \pm 0.07^{* *}$ & $3.01 \pm 0.04^{* *}$ \\
\hline Results were in mean \pm SEM, each group had six rats, $*$ p $<0.001$. SEM: Standard \\
error of mean, APE: Abrus precatorius extracts
\end{tabular}

Table 3: Effect of Abrus precatorius Linn. leaves on free and total gastric acidity during acetic acid-induced gastric ulcer in albino rats

\begin{tabular}{lll}
\hline Group & $\begin{array}{l}\text { Free acidity } \\
\text { (mEq/1/100 g) }\end{array}$ & $\begin{array}{l}\text { Total acidity } \\
\text { (mEq/1/100 g) }\end{array}$ \\
\hline Control (normal) & $12.31 \pm 0.48$ & $32.29 \pm 0.54$ \\
Acetic acid (disease control) & $23.60 \pm 1.16^{* *}$ & $74.24 \pm 2.91^{* *}$ \\
Acetic acid+omeprazole & $12.95 \pm 0.49^{* *}$ & $34.35 \pm 1.95^{*}$ \\
$20 \mathrm{mg} / \mathrm{kg})$ & & \\
Acetic acid+APE (150 mg) & $13.45 \pm 0.57^{* *}$ & $43.76 \pm 0.95^{* *}$ \\
Acetic acid+APE (300 mg) & $12.35 \pm 0.52^{*}$ & $40.76 \pm 0.51^{* *}$ \\
\hline APE: Abrus precatorius extracts & &
\end{tabular}

J Appl Sci Environ Manage 2005;9:85-8.

4. Emmanuel N, Claudette D. Abortifacient plants of the Buea region, their participation in the sexuality of adolescent girls. Indian J Tradit Knowl 2007;6:502-7.

5. Ranju SP, Ariharasivakumar G, Kundlik G, Ashutosh U. In vitro anti oxidative active activity of phenolic and flavonoid compounds extracted from seeds of Abrus precatorius. Int J Pharm Pharm Sci 2009;1:136-40.

6. Saganuwan SA, Gulumbe ML. In vitro antimicrobial activities testing of Abrus precatorius cold water leaf extract on Salmonella typhimurium, Escherichia coli and Klebsiella pneumoniae. J Technol Res 2005;4:70- 3 .

7. Ouattara K, Tuo K, Doumbia I, Coulibaly A. Evaluation of the antibacterial activities of the aqueous extract, alkaloids and flavonoids from Abrus precatorius Linn, (Fabaceae). J Chem Pharm Res 2012:4:4795-9.

8. Anbu J, Ravichandiran V, Sumithra M, Chowdary SB, Kumar KS, Kannadhasan R, et al. Anti cancer activity of petroleum ether extract of Abrus precatorius of ehrlich ascitis carcinoma in mice. Int J Pharm Bio Sci 2011;2:24-31.

9. Duke JA, Bogenschutz-Godwin MJ, duCellier J, Duke PA. Handbook of Medicinal Herbs. $2^{\text {nd }}$ ed. Boca Raton, New York, Washington DC: CRC Press; 2002. p. 114

10. Chaudhari KS, Sharma R, Pawar PS, Kashikaar VA. Pharmacological activities of Abrus precatorius Linn.-a review. Int J Ayurvedic Herb Med 2012;2:336-48.

11. Nadkarni KM. The Indian Materia Medica. Vol. 1. Mumbai: Popular Prakashan; 2002. p. 284.

12. Solanki A, Zaveri M. Pharmacognosy, photochemistry and pharmacology of Abrus precatorius leaf: A review. Int J Pharm Sci Rev Res 2012;13:71-6.

13. Satyavati GV, Raina MK, Sharma M. Medicinal Plants of India. New Delhi: Indian Council of Medical Research; 1987.

14. Mølgaard P, Nielsen SB, Rasmussen DE, Drummond RB, Makaza N, Andreessen J. Anthelmintic screening of zimbabwean plants traditionally used against schistosomiasis. J Ethnopharmacol 2001;74:257-64.

15. Rashmi A, Naresh GS, Sukhuwinder K, Deep JA. Phytopharmacological evaluation of ethanolic extract of the seeds of Arbus precatorius Linn. J Pharmacol Toxicol 2011;6:580-8. 